\title{
The Customer Satisfaction of the Drinking Water in the Coastal of Semarang and the Risk Management
}

\author{
Budiyono Budiyono*, Citrandy Pamungkas, Yusniar Hanani Darundiati \\ Environmental Health Department, Faculty of Public Health, Diponegoro University, Semarang, \\ Indonesia
}

\begin{abstract}
The water supply system is vital for inhabitants living in the coastal area. The water supply system in the coastal of Semarang $60 \%$ served by private. There is no information related to the private service of deep groundwater supply and customer satisfaction. This was an observational research with a cross-sectional. The samples were 40 of the service providers of deep groundwater and 40 customers obtained by accidental sampling. Data were collected by observation and interviewed by using questionnaires. Statistical analysis used the Chi-Square test with an estimated error of 5\%. The results showed that the overall aspects of the service of deep groundwater supply in the good category were $22.5 \%$. The overall perception of customer satisfaction showed in the satisfied category was 55 $\%$. There was a significant association between the less good service of deep groundwater supply and the less satisfaction of the customer under the aspect of quality $(p=0.006)$, quantity $(p=0.001)$, continuity $(p<0.001)$, and the overall of the service aspects $(\mathrm{p}=0.027)$. There was no significant association between affordability and the poor perception of customer satisfaction $(p=0.736)$. The research concluded the less good service of deep groundwater supply and less satisfied with the customer in the coastal of Semarang. The quality, quantity, and continuity of drinking water may risk in health customers.
\end{abstract}

\section{Introduction}

The coverage of drinking water in the city of Semarang was $61.58 \%$ of the total population [1]. The water supply system in Semarang served by the local government water supply system and others were served by private i.e., groundwater or artesian wells, bottled water, or mobile water vendors. Most residents (92.24\%) in the coastal of Semarang use water from groundwater and managed by private service providers. The water used for daily needs i.e., drinking, bathing, and washing [2].

Water service through artesian wells is still not optimal. Based on preliminary study, 9 out of 20 artesian wells in the coastal area did not meet bacteriological requirements and 33 of 41 drinking water samples contaminated E. coli. Besides, there are also various complaints

* Corresponding author: budiyonofkm@lecturer.undip.ac.id 
from consumers related to water quality such as saltiness and the physical condition of turbid water and water flow that is often jammed [2].

Basic service parameters of drinking water are closely related to customer satisfaction, especially from the aspect of quality, quantity, continuity, and affordability. The quality aspect which includes physical quality, bacteriological quality, and supply system; the quantity aspect which includes the amount of water available; aspects of continuity which include consistency of time of delivery; and the aspect of affordability, namely the selling price of water-related to the ability of consumers [3-5]. Artesian well water services related to the satisfaction received by customers have not been much studied. This study aims to examine whether the artesian well drinking water service is related to customer satisfaction in the coastal of Semarang.

\section{Methods}

The study was an observational study with a cross-sectional design to analyze the relationship between artesian well water service and customer satisfaction. The study was conducted in the area Sub-District of North Semarang, Semarang City. The population used is all artesian well service providers, as many as 20 service providers in Bandarharjo village and 20 service providers in Tanjung Mas village. Costumers of artesian drinking water are 1,335 households in Bandarharjo village and 2,152 households in Tanjung Mas village. The sample used is a non-random sample for service providers, as many as 40 artesian well service providers and 40 of the costumers of drinking water from those artesian wells service in the two villages.

The instruments used in this study were observation checklist and questionnaires for structured interviews with artesian well water service providers and costumers. Measurement of odor and taste using organoleptic tests. Quality measurements are also carried out by laboratory analysis specifically for physical quality (turbidity) with turbidimeter and bacteriological quality or total coliform by MPN method. The contents of the questions related to drinking water services in terms of quality, quantity, continuity, and affordability of prices, as well as perceptions of customer satisfaction with drinking water services. The satisfaction of service measured using the formula of Community Satisfaction Index by Administrative and Bureaucratic Ministry of Indonesia [6].

The artesian well water service variable is measured from the aspects of quality, quantity, continuity, and affordability (affordability) provided by providers of artesian well water services using a Likert's scale [7-9]. Thus interviews and observations aimed at service providers. The service aspects of artesian well water are described and assessed as follows: The quality aspect consists of the physical quality of water provided by the service provider of artesian well water which is observed based on water clarity indicators for scale 1 . Very turbid ( $>50 \mathrm{NTU}), 2$. Turbid (11-50 NTU), 3. Somewhat turbid (6- $10 \mathrm{NTU}), 4$. Not turbid/clear $(\leq 5 \mathrm{NTU})$; odorless indicator for scale 1. Very odorous, 2. Smelled, 3. Somewhat odorless, 4. Odorless; and tasteless indicators for scale 1. Very salty, 2. Salty, 3. Somewhat salty, 4 Not salty/tasteless). Bacteriological quality indicator based on the results of total coliform tests in the laboratory for scale 1 . Very much contains bacteria $(>2400 / 100 \mathrm{ml}$ sample), 2. May contain bacteria (10-2400/ $100 \mathrm{ml}$ sample), 3. Slightly contains bacteria ( $<10 / 100 \mathrm{ml}$ sample), 4. It does not contain bacteria (0/100 ml sample) [10].

Quality aspects of the supply system include reservoir drain for scale 1. Never drain, 2. Ever drained (once a year), 3. Rarely drained (once every 3 months), 4. Frequently drained (once a month). Checking the distribution pipe for scale 1. Never checking, 2. Never checking (once a year), 3. Rarely checking (once every 3 months), 4. Frequently checking (once a month). The condition of the distribution pipe is submerged in the event of a tidal for scale 1. Always submerged / every day, 2. Often submerged (if ordinary tidal inundation), 3 . Occasionally submerged (if there is a large tidal), 4. Never submerged (elevated and not 
exposed rob). Pipeline leaks for scale 1. Frequent leakage (occurs within \pm 1 month), 2 . Sometimes it leaks (occurs within \pm 3 months), 3. Rarely occurs leak (occurs within a period of each \pm 1 year), 4 . Never leaked. Artesian well owners make repairs in the event of damage or leakage to scale 1 . Never make repairs, 2. Never make repairs (in a very long period time> 1 year), 3. Rarely do repairs (any damage is not directly repaired), 4. Always make repairs (any damage is repaired immediately) [10].

The quantity aspect with an indicator of the amount of water available per day is 300 liters/household/day. This figure is based on average water usage in the local community. Amount of water available to meet daily water needs for scale 1 . Not enough $(<100 \mathrm{l} / \mathrm{hh} / \mathrm{d})$, 2 . Not enough $(100-<150 \mathrm{l} / \mathrm{hh} / \mathrm{d}), 3$. Enough $(150-<300 \mathrm{l} / \mathrm{hh} / \mathrm{d}), 4$. Very enough / excess $(\geq 300 \mathrm{l} / \mathrm{hh} / \mathrm{d})$.

The continuity aspect includes the measurement of the continuity or consistency of water flow that is carried out every day. Time of drainage carried out by service providers for scale 1. Never drain, 2. Rarely drained $(<12$ hours/day), 3. Sometimes drained (only \pm 12 hours/day), 4. Always drained (24 hours /day). Smooth flowing water for scale 1 . Not flowing at all, 2. Not smooth (more often jammed), 3. Not smooth (sometimes flowing sometimes jammed), 4. Smooth (flowing at any time). Drainage of water in the event of a power failure for a scale 1. Water cannot flow at all or compounded frequent and seasonal discontinuity, 2 . Water runs stagnant (sometimes it flows sometimes not) or seasonal service variation resulting from source fluctuation, 3. Water flows a little (still flows but flows are small) or daily or weekly interruption, 4 . Water flows smoothly (keeps flowing normally along a year) [11].

The affordability aspect is the water tariff imposed by providers of artesian water services to each of their consumers. Affordability of water tariffs for scale 1 . Very unreachable (very far above the average price, $>$ IDR 3,500), 2. Less affordable (above average prices, IDR $>2,600-3,500$ ), 3. Affordable (according to average prices, IDR $>2,500-2,600$ ), 4 . Very affordable (below-average price, IDR 1,500-2,500).

Values obtained from each respondent based on the scale on various aspects of the artesian well water service are then made into a composite. For example, for the quality aspect, there are nine questions, the quantity aspect is one question, the continuity aspect is three questions, the affordability aspect is one question. Each aspect is then categorized as good and not/less good. Furthermore, the overall service is a composite value from all aspects of artesian well water service which is categorized as satisfied and less satisfied.

The variable of customer satisfaction is the perception of consumers or customers of artesian well water on the services provided by providers of artesian well water services. The variables of satisfaction perception related to artesian well water service include the same aspects as artesian well water service providers, namely quality, quantity, continuity, and affordability. Likewise, the ratings and categories are the same, for example on a scale of 4 = Very Satisfied, 3 = Satisfied, 2 = Less Satisfied; and 1 = Dissatisfied.

The values given are based on a scale on various aspects of customer satisfaction from artesian well water services then composite values are made. For example, for customer satisfaction from the aspect of quality there are nine questions, customer satisfaction from the aspect of quantity there is one question, customer satisfaction from the aspect of continuity there are three questions, customer satisfaction from the aspect of affordability there is one question. Each aspect of customer satisfaction is then categorized as satisfied and less satisfied. Furthermore, overall customer satisfaction with service is a composite value of all aspects of artesian well water services which are categorized as satisfied and less satisfied. To determine the relationship between drinking water service of the artesian (groundwater) and the perception of customer satisfaction a relationship test was performed. Based on service categories and perceptions categories of customer satisfaction from each aspect and 
all aspects including quality, quantity, continuity, and reliability, statistical analysis was performed using the Chi-square test with an error rate of $5 \%$.

\section{Results}

The northern coastal area of Semarang City is an area prone to tides due to its location which is directly adjacent to the sea. This region is a low-lying area with altitudes reaching $0,5 \mathrm{~m}$ above sea level. The total area of the two villages is 342,675 hectares and 384,415 hectares, respectively. Based on the monograph 2013 of Bandarharjo village, the population is 20,553 people with 4,330 families. While Tanjung Mas village has a population of 30,651 people with 7,525 households.

Table 1. Demographic characteristic

\begin{tabular}{|c|c|c|c|}
\hline & Demographic characteristics & Frequent & $\%$ \\
\hline \multirow[t]{4}{*}{1} & Age of drinking water service provider & & \\
\hline & $20-29$ years old & 1 & 2.5 \\
\hline & $30-39$ years old & 7 & 17.5 \\
\hline & $\geq 40$ years old & 32 & 80 \\
\hline \multirow[t]{4}{*}{2} & Age of the respondents & & \\
\hline & 20-29 years old & 6 & 15 \\
\hline & 30-39 years old & 10 & 25 \\
\hline & $\geq 40$ years old & 24 & 60 \\
\hline \multirow[t]{5}{*}{3} & Occupation of the respondents & & \\
\hline & Worker & 4 & 10 \\
\hline & Housewife & 22 & 55 \\
\hline & Small trader & 6 & 15 \\
\hline & Private & 8 & 20 \\
\hline \multirow[t]{4}{*}{4} & Educational level of the respondents & & \\
\hline & Elementary school & 9 & 22.5 \\
\hline & Junior high school & 19 & 47.5 \\
\hline & Senior high school & 12 & 30 \\
\hline \multirow[t]{4}{*}{5} & Income of the respondents (IDR) & & \\
\hline & $<1,000,000$ & 9 & 22.5 \\
\hline & $1,000,000-1,500,000$ & 28 & 70 \\
\hline & $>1,500,000$ & 3 & 7.5 \\
\hline
\end{tabular}

The age of respondents for artesian service provider $\geq 40$ years is $80 \%$, while the age of consumer respondents $\geq 40$ years is $60 \%$. Consumers are mostly housewives $(55 \%)$ and consumer education at junior high school graduates by $47.5 \%$. The monthly income of most consumers (70\%) is Rp. 1,000,000-1,500,000. 
Table 2. The Aspects of Drinking Water Service

\begin{tabular}{|c|c|c|c|}
\hline \multicolumn{2}{|c|}{ The Aspects of Service } & \multirow[t]{2}{*}{ Frequent } & \multirow[t]{2}{*}{$\%$} \\
\hline 1 & Quality of the drinking water & & \\
\hline & Less good & 23 & 57.5 \\
\hline & Good & 17 & 42.5 \\
\hline \multirow[t]{3}{*}{2} & Quantity of the drinking water & & \\
\hline & Less good & 12 & 30 \\
\hline & Good & 28 & 70 \\
\hline \multirow[t]{3}{*}{3} & Continuity of the drinking water & & \\
\hline & Less good & 23 & 57.5 \\
\hline & Good & 17 & 42.5 \\
\hline \multirow[t]{3}{*}{4} & Affordability of the drinking water & & \\
\hline & Less good & 15 & 37.5 \\
\hline & Good & 25 & 62.5 \\
\hline \multirow[t]{3}{*}{5} & Overall services of the drinking water & & \\
\hline & Less good & 31 & 77.5 \\
\hline & Good & 9 & 22.5 \\
\hline
\end{tabular}

More than $50 \%$ of drinking water from artesian wells is in terms of quantity and affordability in the good service category. As for the quality and continuity aspects of more than $50 \%$ in the less good service category.

Table 3. The level of the customer satisfaction perception of the aspects of drinking water service

\begin{tabular}{|c|c|c|c|}
\hline & Level of satisfaction of the customer & Frequent & $\%$ \\
\hline \multirow[t]{3}{*}{1} & Quality of the drinking water & & \\
\hline & Less satisfied & 24 & 60 \\
\hline & Satisfied & 16 & 40 \\
\hline \multirow[t]{3}{*}{2} & Quantity of the drinking water & & \\
\hline & Less satisfied & 18 & 45 \\
\hline & Satisfied & 22 & 55 \\
\hline \multirow[t]{3}{*}{3} & Continuity of the drinking water & & \\
\hline & Less satisfied & 16 & 40 \\
\hline & Satisfied & 24 & 60 \\
\hline \multirow[t]{3}{*}{4} & Affordability of the drinking water & & \\
\hline & Less satisfied & 12 & 30 \\
\hline & Satisfied & 28 & 70 \\
\hline \multirow[t]{3}{*}{5} & Overall services & & \\
\hline & Less satisfied & 18 & 45 \\
\hline & Satisfied & 22 & 55 \\
\hline
\end{tabular}

Table 3 shows that more than $50 \%$ of artesian water consumers expressed satisfaction with the service as a whole, as well as for the aspects of quantity, continuity, and affordability. But on the other hand, more than $50 \%$ of consumers expressed less satisfaction with the quality aspect. 
Table 4. The association between the services of drinking water and customer satisfaction perception

\begin{tabular}{|c|c|c|c|c|c|}
\hline \multirow[t]{3}{*}{ The category of services } & \multicolumn{4}{|c|}{ Customer satisfaction perception } & \multirow[t]{3}{*}{ p-value } \\
\hline & \multicolumn{2}{|c|}{ Less satisfied } & \multicolumn{2}{|c|}{ Satisfied } & \\
\hline & $\mathrm{n}$ & $\%$ & $\mathrm{n}$ & $\%$ & \\
\hline \multicolumn{6}{|l|}{$\begin{array}{l}\text { Quality of the drinking } \\
\text { water }\end{array}$} \\
\hline Less good & 18 & 78.3 & 5 & 21.7 & 0.006 \\
\hline Good & 6 & 35.3 & 11 & 64.7 & \\
\hline \multicolumn{6}{|l|}{$\begin{array}{l}\text { Quantity of the drinking } \\
\text { water }\end{array}$} \\
\hline Less good & 10 & 83.3 & 2 & 16.7 & 0.001 \\
\hline Good & 8 & 28.6 & 20 & 71.4 & \\
\hline \multicolumn{6}{|l|}{$\begin{array}{c}\text { Continuity of the drinking } \\
\text { water }\end{array}$} \\
\hline Less good & 15 & 65.2 & 8 & 34.8 & $<0.001$ \\
\hline Good & 1 & 5.9 & 16 & 94.1 & \\
\hline \multicolumn{6}{|l|}{$\begin{array}{l}\text { Affordability of the } \\
\text { drinking water }\end{array}$} \\
\hline Less good & 5 & 33.3 & 10 & 66.7 & 0.736 \\
\hline Good & 7 & 28 & 18 & 72 & \\
\hline
\end{tabular}

Based on Table 4, it was found that the service of poor water quality is associated with less satisfied consumers of the water quality service. Service in terms of an adequate amount of water and water availability is related to customer satisfaction with artesian water delivery. The affordability of prices is not related to customer satisfaction of artesian water.

Table 5. The relationships between overall aspects of service and overall customer satisfaction perceptions

\begin{tabular}{cccccc}
\hline \multirow{2}{*}{ Overall services } & \multicolumn{3}{c}{ Overall customer satisfaction } & \multirow{2}{*}{ p-value } \\
\cline { 2 - 5 } & \multicolumn{2}{c}{ Less satisfied } & \multicolumn{2}{c}{ Satisfied } & \\
\cline { 2 - 5 } & $\mathrm{n}$ & $\%$ & $\mathrm{n}$ & $\%$ & 0.027 \\
\hline Less good & 17 & 54.8 & 14 & 45.2 & \\
Good & 1 & 11.1 & 8 & 88.9 & \\
\hline
\end{tabular}

Table 5 overall shows that poor artesian drinking water service is significantly related to the perception of unsatisfied consumers.

\section{Discussion}

Service in terms of artesian well water quality is related to customer satisfaction perceptions. Consumer satisfaction is the satisfaction or dissatisfaction experienced by linking previous expectations regarding a service or product [12]. Satisfaction can also be someone's feelings of pleasure or disappointment that results from comparing the performance or results felt by a product with their expectations [13]. Therefore, it is important to conduct a survey that allows measuring customer satisfaction by identifying gaps between expectations and experience [14]. 
The population that uses drinking water sourced from artesian wells in Semarang City is $54.7 \%$ [15]. Of all artesian wells owned by artesian drinking water service providers that have been studied in a laboratory, most have met the physical and bacteriological quality requirements, although there are some wells whose water is still salty and the turbidity and MPN coliform numbers are still above the specified conditions. The character of the water is possible because of seawater intrusion [16]. This may occur due to the location of the study in the coastal area. Water quality is a key indicator in the satisfaction of consumers of drinking water 9. Turbidity is an indicator that can be seen visually, so this physical quality will be easily detected by consumers. Besides the smell and taste of water is also easily detected using the senses. The quality of drinking water will easily change with the conditions that accompany it, for example, a reservoir that is not drained (33.5\%) will be mossy and cause the water in it to become turbid. Leakage of distribution pipes and house connection pipes $(17.5 \%)$ will also cause water in the pipes to become turbid and smelly. This is because the distribution pipes installed in the two urban areas pass through sewers and are submerged by tidal water mixed with sewer water $(27.5 \%)$. This murky, smelly, and tasteless condition was found in a previous study [17]. The condition of drinking water from artesian wells that looks turbid, smelly, and tastes salty $(22.5 \%)$ will create public attention, especially in a risk of health perspective and influence perceptions of consumer dissatisfaction [18]. The taste of salty drinking water is also a complaint from water consumers. These indicators are also used to measure consumer satisfaction in other studies $[3,19]$.

Besides the physical quality of water, bacteriological quality, namely the presence of pathogenic microorganisms, is the most important indicator because it is directly related to the human health that consumes it. According to WHO and Ministry of Health decree number $492 / 2010$ that the bacteriological quality of drinking water must be absent or absent from Escherichia coli and as an alternative is the presence of thermotolerant coliform bacteria [4]. Although in this study consumers could not identify the presence of pathogenic germs, the results of the study found that most were positive fecal coliforms $(42.5 \%)$. The presence of coliform bacteria is caused by the absence of disinfection in the artesian well drinking water treatment system. So, it needs to be done disinfection both chemically and physically according to standards that have been carried out in the supply of drinking water according to WHO [20].

The condition is turbid, smelly, tastes and the presence of coliform bacteria which is possible due to pipe leaks or other contamination needs to be immediately repaired. The conditions will affect the risk of health customers. According to previous research that public attention related to water pollution control is low [15]. The potential health risk of customers can be managed by minor repair. Efforts to make improvements such as connecting loose or leaky pipes are carried out by $95 \%$ of artesian well water service providers.

Water quantity is related to customer satisfaction of artesian well water. The capacity of the smallest reservoir is $3 \mathrm{~m}^{3}$ and the largest is $18 \mathrm{~m}^{3}$ with an average capacity of $4.98 \mathrm{~m}^{3}$. The service in terms of quantity which includes the amount of available water is measured based on the capacity of the reservoir that must be able to meet the average needs of consumer water for drinking, washing, and cooking that is as much as 300 liters/household/day. The capacity of the water reservoir provided by the artesian well water service provider is quite capable of providing consumers' needs, so this is perceived by consumers better. As many as $70 \%$ are included in the category of good service in the sense that it is sufficient to meet the number of needs of consumers. The water requirement for daily needs in Indonesia is 150 liters/person/day. This need is sufficient when compared to Kenya, $72 \%$ of households have water needs of 15-251/capita/day and this finding also shows a relationship of a quantity of water sufficiency with consumer satisfaction $(p<0.001)$ [21]. The optimal access in term of quantity to water is $100-200 \mathrm{l} /$ capita/day with the category of public health risk from poor hygiene is very low [11]. 
Poor service in terms of continuity is related to the perception of dissatisfaction with artesian consumers. Sustainability or continuity is another indicator of consumer satisfaction with drinking water [9]. The ability of artesian drinking water service providers to deliver water to consumers' homes for 24 hours non-stop (70\%), never experience traffic jams or shut down (85\%), and the ability to keep running water when power cuts occur $(57.5 \%)$. Based on this, not all artesian well water service providers can provide artesian well water continuously ( 24 hours a day). This is because to start the engine pump so that it can run automatically requires quite high electrical power and cost a lot. So that most service providers only turn on the pump engine 4-5 hours per day.

Besides the power cut from national power plant is a separate reason for not being able to turn on the water pump and produce water. This is because the production of drinking water from artesian wells is highly dependent on electricity. After all, because it uses an electric water pump. All (100\%) artesian well water service providers do not have generator sets that can replace electricity from the national power plant. So that practically in the event of a power outage from the national power plant, the service provider only relies on the existing water storage capacity. If the electricity fails, the ability of the water reservoir to guarantee the availability of water to all consumers is only a few hours. Another thing that disturbs the continuity of the artesian well water supply to consumers is the bottleneck of the pump or distribution system, and this can be long or short. The reduced amount of water in the reservoir also affects water pressure in the distribution pipes and house connection pipes, so that the flow is small. So that the availability of electricity is a major factor in water production [22]. This condition is perceived by consumers as not in line with expectations, causing dissatisfaction. As it is known that aspects of service continuity are influenced by the availability of electricity, water pressure, water reserves [3,5]. The price of water is not related to customer satisfaction of artesian well water. Based on interviews it is known that the average water price is IDR. 2,662.00. While each service provider applies a rate that varies between IDR. 1,500.00 to IDR. 3,500.00. When compared with local government's drinking water tariffs, artesian well water prices are slightly higher, although not too significant. Most consumers feel that the tariff charged is still affordable, not too much different from the local government's water tariff. Only some consumers feel that the tariff charged is still less affordable but they will still buy the water because artesian well water is the main source of water.

Based on the results of the study showed overall the artesian well water service that is less good is related to consumer dissatisfaction. This is indicated by the fact that more service providers do not meet all four aspects of service well (77.5\%) and consumers are less satisfied $(45 \%)$. This is because drinking water services in the Bandarharjo and Tanjung Mas villages are conducted by individuals, in terms of available resources and facilities that are still limited compared to those provided by state-owned or regionally-owned or private-owned business entities. Only a small proportion of service providers can meet the overall drinking water service requirements which cover four aspects. Therefore, it is important to manage potential health risk by monitoring the source, distribution, and house connections to ensure the quality and continuity of water [23].

Limitations in this study are that not all aspects or variables of drinking water services and customer satisfaction perceptions are measured. Need to use a larger sample.

\section{Conclusion}

Inadequate drinking water service from artesian wells provider is related to customer dissatisfaction in the coastal area of Semarang. To manage potential health risk needs for disinfection, providing adequate storage tanks, or having a generator set to ensure the quality and availability of drinking water from artesian wells continuously. For customers of artesian 
drinking water should immediately report to the service provider if the quality and continuity of the water they get is not guaranteed. Besides, costumers should report immediately if there are leakage and pipe damage to immediately take corrective action.

\section{References}

1. Indonesian Urban Water Sanitation and Hygiene (IUWASH)-USAID. Supporting Semarang Equity to Access to Water and Sanitation, (online), 2013, Available on https://www.iuwashplus.or.id/cms/wp-content/uploads/2017/05/Profil-Program-KotaSemarang-ID.pdf, accessed 24 September 2013)

2. B. Budiyono, P Ginandjar, L.D. Saraswati, D.R. Pangestuti, Martini, S.P. Jati, Z. Rahfiludin. Risk assessment of drinking water supply system in the tidal inundation area of Semarang - Indonesia. Procedia Environmental Sciences. 23, 93-98 (2015). doi: 10.1016/j.proenv.2015.01.014

3. P. Fattahi, A. Kherikhah, R. Sadeghian, S. Zandib, S. Fayyaz. An evaluation model for measuring customer satisfaction levels in a water supply domain: case study - water supply in Hamedan. Water Policy 13, 490-505 (2011). doi:10.2166/wp.2010.123

4. WHO. Guidelines for drinking-water quality - 4th ed. WHO Press, World Health Organization, 20 Avenue Appia, 1211 Geneva 27, Switzerland. Pp 83-86 (2011).

5. K.P. Jayaramu, K.B. Manoj, R.K. Prasanna. Customer Satisfaction with Domestic Water Supply in India - A Study in Hubli city. Journal of Environment and Earth Science. Vol.4, No.9 (2014). https://iiste.org/Journals/index.php/JEES

6. Ministry of Administrative Reform. Decree of the Minister of Administrative Reform Number: Kep/25/M.PAN/2/2004 concerning General Guidelines for the Preparation of Community Satisfaction Indexes for Government Institution Service Units.

7. E.A. Donkor. Effect of customer satisfaction on water utility business performance. Journal-American Water Works Association. 105 (10): E553-E560 (2013). http://dx.doi.org/10.5942/jawwa.2013.105.0114

8. J. Noga and G. Wolbring. Perceptions of Water Ownership, Water Management, and the Responsibility of Providing Clean Water. Water 5, 1865-1889 (2013). doi:10.3390/w5041865

9. V.R. Shinde, N. Hirayama, S. Itoh. Development of evaluation model for consumers' satisfaction of water supply service. www.witpress.com, ISSN 1743-3541 (on-line) WIT Transactions on Ecology and The Environment, Vol 178, 215-223 (2014) WIT Press. doi:10.2495/WS130181

10. J. Bartram, L. Corrales, A. Davison, D. Deere, D. Drury, B. Gordon, G. Howard, A. Rinehold, M. Stevens. Water safety plan manual: step-by-step risk management for drinking-water suppliers. World Health Organization, Geneva, (2009)

11. WHO. Guidelines for drinking-water quality [electronic resource]: incorporating 1 st and 2nd addenda, Vol.1,Recommendations.- 3rd ed (2008).

12. A. Qazi, Tamjidyamcholo A, Raj RG, Hardaker G, Standing C. Assessing consumers' satisfaction and expectations through online opinions: Expectation and disconfirmation approach. Computers in Human Behavior 75,450-460 (2017). http://dx.doi.org/10.1016/j.chb.2017.05.025

13. P. Kotler and K.L. Keller. Marketing Management. Pearson Education, Inc., publishing as Prentice Hall,One Lake Street, Upper Saddle River,New Jersey 07458 (2012). P 10

14. K. Hormann. Consumer Satisfaction with Water, Wastewater and Waste Services in Portugal. Nova School of Business and Economics. Campus de Campolide, P-1099-032 (2016) Lisboa, Portugal

15. T. Joko and N.A.Y. Dewanti. Survey of Drinking Water and Sanitation in Local Government Semarang, Salatiga, Kendal and Pekalongan District. International 
SAMANM Journal of Finance and Accounting. Vol. 4, No. 1.:1-12 (2016). https://www.srpublishers.org/uploads/4/3/6/9/43696183

16. E. Suhartono, P. Purwanto, and S. Suripin. Conditions of Sea Water Intrusion Against Ground Water in Aquifers in the City of Semarang. Proceedings of the National Seminar on Management of Natural Resources and the Environment, 2013. https://www.researchgate.net/publication/328316422_Prosiding_Seminar_Nasional_Pe ngelolaan_Sumberdaya_Alam_dan_Lingkungan_Semarang

17. B. Budiyono, P. Ginandjar, L.D. Saraswati, D.R. Pangestuti, Martini, S.P. Jati. Implementation of Water Safety Plans (WSPs): A Case Study in the Coastal Area in Semarang City, Indonesia. (2018) IOP Conf. Ser.: Earth Environ. Sci. 116 012029:1-13

18. L. Wang, L. Zhang, J. Lv, Y. Zhang, B. Ye. Public Awareness of Drinking Water Safety and Contamination Accidents: A Case Study in Hainan Province, China. Water, 10, 446:1-15 (2018). doi:10.3390/w10040446

19. A.V. Kulinkina, J.D. Plummer, K.K.H. Chui, K.C. Kosinski, T. Adomako-Adjei, A.I. Egorov, E.N. Naumova. Physicochemical parameters affecting the perception of borehole water quality in Ghana. International Journal of Hygiene and Environmental Health. 220, 990-997 (2017). http://dx.doi.org/10.1016/j.ijheh.2017.05.008

20. WHO. Water Safety in Distribution Systems. WHO Press, World Health Organization, 20 Avenue Appia, 1211 Geneva 27, Switzerland. Pp 14-18 (2014)

21. K.N. Zeraebruka, A.O. Mayabib, J.M. Gathenyac, Z. Tsiged. Assessment of Level and Quality of Water Supply Service Delivery for Development of Decision Support Tools: Case Study Asmara Water Supply. International Journal of Sciences: Basic and Applied

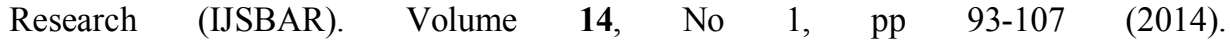
http://gssrr.org/index.php?journal=JournalOfBasicAndApplied

22. C.M. Chini and A.S. Stillwell. The state of U.S. urban water: Data and the energy-water nexus. Water Resources Research, 54, 1796-1811 (2018). https://doi. org/10.1002/2017WR022265

23. A.J. Whelton, A.M. Dietrich, D.L. Gallagher, J.A. Roberson. Using Customer Feedback for Improved Water Quality and Infrastructure Monitoring. Journal AWWA. 99 (11):6276 (2007). DOI: 10.1002/j.1551-8833.2007.tb08081.x 